\title{
Article \\ A Brief Study on Optical and Mechanical Properties of an Organic Material: Urea Glutaric Acid (2/1) - A Third Order Nonlinear Optical Single Crystal
}

\author{
C. Rathika Thaya Kumari ${ }^{1}$, Ahmed Al Otaibi ${ }^{2}$, T. Kamaraj ${ }^{3}$, M. Nageshwari ${ }^{1}$, G. Mathubala ${ }^{4}$, \\ Ayyar Manikandan 4,5®, M. Lydia Caroline ${ }^{6, *}$, S. Sudha ${ }^{7}$, Heba Abbas Kashmery ${ }^{8}$, P. Madhu ${ }^{9}$, \\ Anish Khan ${ }^{8,10, *}$, Hadi M. Marwani ${ }^{10}$ and Abdullah M. Asiri ${ }^{8,10}$
}

check for updates

Citation: Kumari, C.R.T.; Al Otaibi,

A.; Kamaraj, T.; Nageshwari, M.;

Mathubala, G.; Manikandan, A.;

Caroline, M.L.; Sudha, S.; Kashmery,

H.A.; Madhu, P.; et al. A Brief Study

on Optical and Mechanical Properties

of an Organic Material: Urea Glutaric

Acid (2/1) - A Third Order Nonlinear Optical Single Crystal. Crystals 2021, 11, 1239. https://doi.org/10.3390/ cryst11101239

Academic Editor: Ana

M. Garcia-Deibe

Received: 8 September 2021

Accepted: 5 October 2021

Published: 14 October 2021

Publisher's Note: MDPI stays neutral with regard to jurisdictional claims in published maps and institutional affiliations.

Copyright: (c) 2021 by the authors. Licensee MDPI, Basel, Switzerland. This article is an open access article distributed under the terms and conditions of the Creative Commons Attribution (CC BY) license (https:/ / creativecommons.org/licenses/by/ $4.0 /)$.
1 Department of Physics, Bharath Institute of Higher Education and Research, Chennai 600 073, India; rathikak06@gmail.com (C.R.T.K.); nageshwari.sb@gmail.com (M.N.)

2 Department of Chemistry, College of Sciences, University of Ha'il, P.O. Box 2440, Hail 81451, Saudi Arabia; ahmed.alotaibi@uoh.edu.sa

3 Department of Mathematics, Sathyabama Institute of Science and Technology, Chennai 600 119, India; kamarajmx@gmail.com

4 Department of Chemistry, Bharath Institute of Higher Education and Research, Chennai 600 073, India; mathubala.che@bharathuniv.ac.in (G.M.); manikandana.che@bharathuniv.ac.in (A.M.)

5 Centre for Catalysis and Renewable Energy, Bharath Institute of Higher Education and Research, Chennai 600 073, India

6 Department of Physics, Dr. Ambedkar Govt. Arts College, Vyasarpadi, Chennai 600 039, India

7 Department of Physics, Arignar Anna Govt. Arts College, Cheyyar 605602, India; sudhavaidhy@gmail.com

8 Chemistry Department, Faculty of Science, King Abdulaziz University, Jeddah 21589, Saudi Arabia; hkashmery@kau.edu.sa (H.A.K.); asiri2@gmail.com (A.M.A.)

9 Department of Mechanical Engineering, Malnad College of Engineering, Hassan, Visvesvaraya Technological University, Belagavi 590018, India; madhu.p.gowda15@gmail.com

10 Center of Excellence for Advanced Materials Research, King Abdulaziz University, Jeddah 21589, Saudi Arabia; hmarwani@kau.edu.sa

* Correspondence: address: lydiacaroline2013@gmail.com (M.L.C.); anishkhan97@gmail.com (A.K.)

Abstract: Urea glutaric acid (UGA), an organic crystal, was synthesized and grown using a low temperature solution technique. Single crystal XRD revealed a monoclinic structure with a C2/C space group. The various cell data were identified. The optical parameters were calculated from UVvisible spectrum. The transmittance spectra showed the cutoff wavelength as $240 \mathrm{~nm}$ (low) and the energy gap determined from the spectra was compared with the theoretical energy gap. The transition number revealed the electron transition, which corresponded to direct allowed transition. The diverse optical parameters like reflectance, extinction coefficient, refractive index and optical susceptibility were determined. The least value of Urbach energy caused less defects and a good crystalline nature. The steepness value and electron phonon interaction were calculated. The positions of lower and higher band energy levels were identified. Electronic polarizability was found using the ClausiusMossoti relation and tabulated. The mechanical fitness was measured from Vickers hardness analysis. The nonlinear optical property was measured from Z-scan analysis. Thus, the optical results support the material suitability and fitness for optical and electronic domain applications.

Keywords: nonlinear optical material; optical studies; energy band gap; urbach energy; solid state parameters; Z-scan technique

\section{Introduction}

Organic crystals with superior characteristics capture the attention of many young researchers because of their wide optical applications in device fabrication, recent advances in laser imaging systems, photonics, information storage, etc. [1]. Most of the interesting organic materials with good NLO properties have motivated a great deal of research 
and have wide transparency windows for easy fabrication of devices and integrated systems [2]. Moreover, for better performance of electronic devices, such as FETs, LEDs and photo cells, these optical characteristics are essential. Large-sized crystals with good NLO efficiency and better structural perfections are quite necessary for practical applications and performance in photonic and optoelectronic devices [3,4]. With all this in view, a single crystal was grown with good organic materials. At the time of crystal incorporation during the growth period, some defects were identified due to a non-equilibrium process. The defect analysis was very important because defect-free single crystals are more applicable for optical applications and device fabrications [5]. More investigations on urea-based organic materials such as urea oxalic acid, urea L-valine, urea thiourea, urea tartaric acid, and urea sulfamic acid, have been extensively studied to display their excellent nonlinear optical behavior, which displayed their significant role, especially in the field of optical communications and frequency conversion applications.

In the present work, the organic molecule glutaric acid $\left(\mathrm{C}_{5} \mathrm{H}_{8} \mathrm{O}_{4}\right)$ is preferred as it has dicarboxylic acid groups, which permit it as an excellent proton donor [6]. In turn, the proton donor nature of glutaric acid was recommended as a foreign molecule in urea and melamine [7-9]. Urea is a popular material well suited for NLO property applications $[10,11]$. Additionally, the depiction of urea and glutaric acid molecules on discrete formations in three different combinations (1: 1, 1:2 and 2:1) were explained and connectivity patterns of the 1:1 complex structure of the compound was discussed [12]. Rathika Thaya Kumari et al. reported the synthesis, growth, and supportive characterizations of UGA [13]. From the information gathered in this present research work, we have discussed the optical and mechanical properties of the title compound and revealed its efficiency in nonlinear optical applications.

\section{Determination of Material Synthesis}

The organic material, UGA, was chosen using the ratio of urea (2) with glutaric acid (1) in a molar ratio 2:1 and synthesized with double distilled water by a slow evaporation technique. The homogeneous stirred solution was filtered, covered, and allowed to evaporate. After 30 days, a moderately sized clear and shiny transparent crystal was sediment in the base of the beaker. This was preserved and photographed. The image was shown in Figure 1.

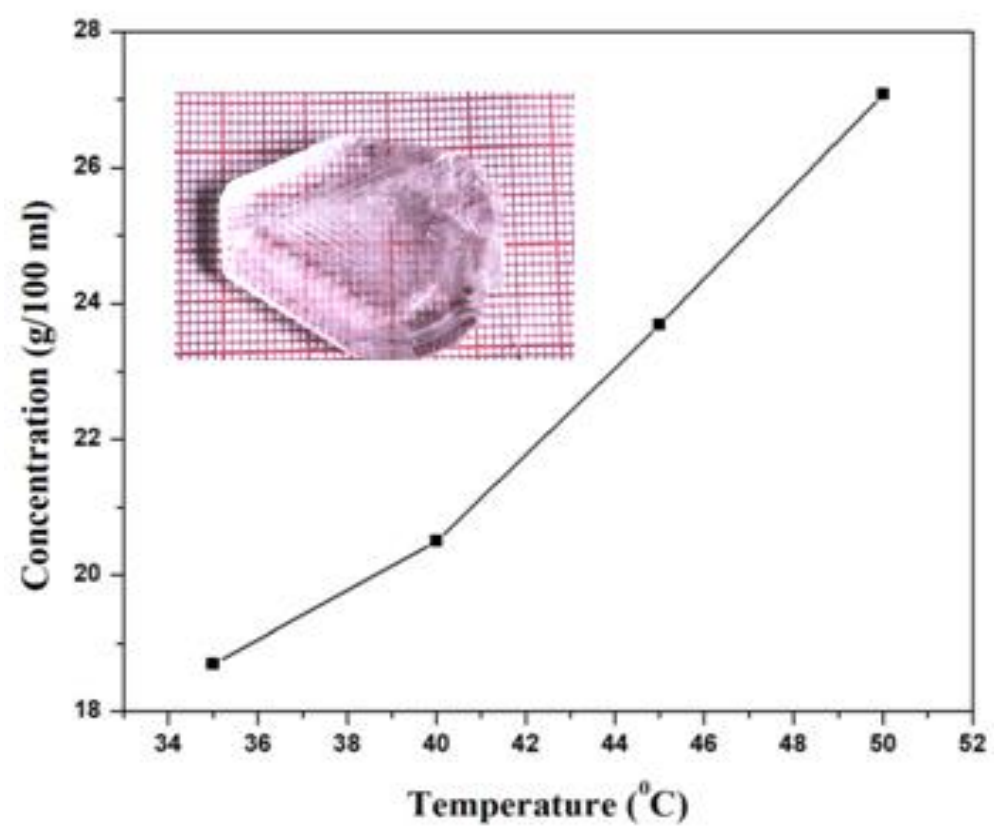

Figure 1. Solubility curve for UGA crystal with grown crystal inside. 


\section{Determination of Solubility}

The data (solubility) of UGA was determined with double distilled water for diverse saturation values of temperature by a gravimetric method. The values are noted for different temperatures and the graph is plotted, which is displayed in Figure 1. From the graph, the solubility of UGA increases linearly with the rise in temperature. The positive nature of the linear curve indicates the opportunity of growing bulk crystal through the evaporation method [14].

\section{Detailed Report on Characterizations}

\subsection{Determination of Single Crystal XRD}

The UGA crystal undergoes single crystal XRD analysis by NONIUS-(CAD4-F) diffractometer with $\operatorname{MoK} \alpha(\AA)$ ray. The result for UGA shows a monoclinic (structure) with the space group of $\mathrm{C} 2 / \mathrm{c}$. Cell data are $\mathrm{a}=12.07 \AA, \mathrm{b}=11.05 \AA, \mathrm{c}=9.17 \AA$ when the volume $\mathrm{V}=1210 \AA^{3}$ was determined. In addition, four-unit cell molecules were reported. The crystal structure data and the molecular structure of UGA are presented in Figure 2 and tabulated in Table 1 . These determined data agrees clearly with the literature already reported [12].<smiles>NC(N)=O</smiles><smiles>NC(N)=O</smiles>

\section{Urea Glutaric acid (2/1)}

Figure 2. Molecular structure for UGA (2/1).

Table 1. Determined crystal data of UGA [12].

\begin{tabular}{|c|c|}
\hline Empirical Formula & $\mathrm{C}_{7} \mathrm{H}_{16} \mathrm{~N}_{4} \mathrm{O}_{6}$ \\
\hline Formula weight & 253.233 \\
\hline Temperature & $24{ }^{\circ} \mathrm{C}$ \\
\hline Crystal structure with space group & $\begin{array}{c}\text { Monoclinic and C2/c } \\
a=14.9230(9)\end{array}$ \\
\hline Cell data (dimensions) in $\AA$ & $\begin{array}{c}\mathrm{b}=6.5971(4) \\
\mathrm{c}=15.7552(10)\end{array}$ \\
\hline Volume in $\AA^{3}$ & 1210 \\
\hline Formula (units) per unit cell & 4 \\
\hline Density in $\mathrm{g} / \mathrm{cm}^{3}$ & 1.425 \\
\hline $2 \theta(\max )$ in deg & $50^{\circ}$ \\
\hline Total reflections & 2184 \\
\hline Reflections (Rind $=0.03$ ) & 1095 \\
\hline Peak $_{\text {(Maximum) }}$ e. $\AA^{-3}$ & 0.16 \\
\hline Peak $_{(\text {Minimum) }}$ e. $\AA^{-3}$ & -0.13 \\
\hline
\end{tabular}

The experimental density value of UGA was determined and correlated with the theoretical density value of UGA. These theoretical data were estimated using the formula [15], Density $=\mathrm{MZ} / \mathrm{NV}$ where $\mathrm{M}, \mathrm{V}$ and $\mathrm{Z}$ represents molar mass, volume and number of molecules in a one-unit cell respectively.

Experimental density was identified to be $1.425 \mathrm{~g} / \mathrm{cm}^{3}$ and theoretically calculated to be $1.407 \mathrm{~g} / \mathrm{cm}^{3}$. This close value shows the purified nature of the grown material.

\subsection{Determination of Transmission in Visible Region}

The optical transmittance range was determined from the UV-visible spectra and was conceded out in the wavelength range between $100 \mathrm{~nm}$ and $800 \mathrm{~nm}$ using a Perkin -Elmer (lambda 35) spectrometer. The wavelength range between $200 \mathrm{~nm}$ and $400 \mathrm{~nm}$ is preferred 
for effective NLO material [16]. If the wavelength cutoff region occurs within this range, then the material suggests good transmittance in the visible region. Figure 3 portrays transmission spectra for the UGA crystal with the lowest cutoff wavelength identified to be $240 \mathrm{~nm}$ as no further absorption occurs from $240 \mathrm{~nm}$ to $800 \mathrm{~nm}$. Hence, the grown material is well suited for nonlinear optical applications.

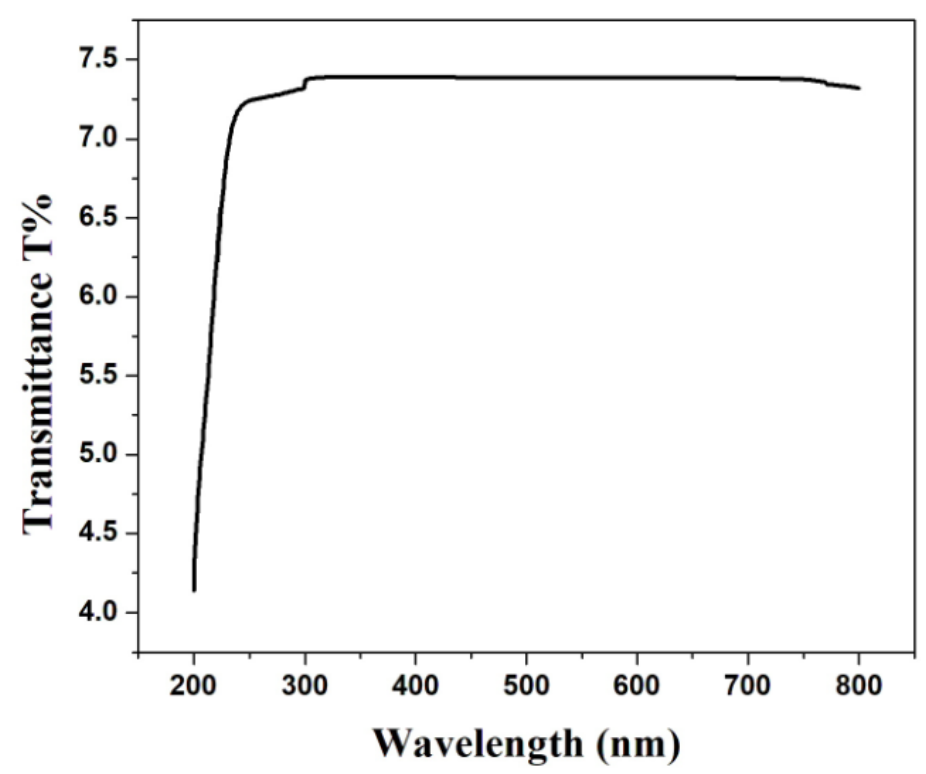

Figure 3. Transmittance spectrum of UGA.

\subsubsection{Determination of $\mathrm{m}$ (Transition Number)}

When EM radiation is allowed to pass through grown material, the radiation will absorb if its energy is almost equal to the band gap energy. At this time, the transition of electrons occurs, which may be either direct or indirect allowed transitions or forbidden transitions based on the transition number $\mathrm{m}$. This transition number is identified from the spectra drawn with $\ln (\alpha \mathrm{hv})$ and $\ln \left(\mathrm{h} v-\mathrm{E}_{\mathrm{g}}\right)$ and is depicted in Figure 4. The transition numbers should be $1 / 2,2,3 / 2$ and 3 for the transition direct, indirect allowed, direct forbidden, and indirect forbidden, respectively [17].

UGA compound $\mathrm{m}$ value was determined to be 0.462 , which was near to 0.5 and corresponds to direct allowed transition.

\subsubsection{Determination of Energy (Band) Gap}

As per Tauc's relation, the absorption coefficient value can be used to estimate band gap of the material $[18,19]$. Thus:

$$
\begin{gathered}
(\alpha \mathrm{h} v)=A\left(\mathrm{~h} v-\mathrm{E}_{\mathrm{g}}\right) \\
\ln (\alpha \mathrm{h} v)=\ln \mathrm{A}+\mathrm{m} \ln \left(\mathrm{h} v-\mathrm{E}_{\mathrm{g}}\right)
\end{gathered}
$$

Hence, $E_{g}$ can be calculated with the reference of Tauc's plot, which is the graph plotted against $(\alpha h v)^{2}$ and $h v$ and depicted in Figure 5. From the graph, Eg for UGA was identified to be $5.46 \mathrm{eV}$ experimentally and was calculated theoretically as $5.175 \mathrm{eV}$. This was estimated from the formula, $E_{g}=h c / \lambda(e V)$. Both experimentally observed and theoretically calculated data were well correlated to show less depth in the absorption edge, which confirms a wide transmission lane in the visible region. Thus, the occurrence of wide band gap of the UGA single crystal is expected to possess enhanced damage threshold values and larger transmittance in the visible spectrum [13]. 


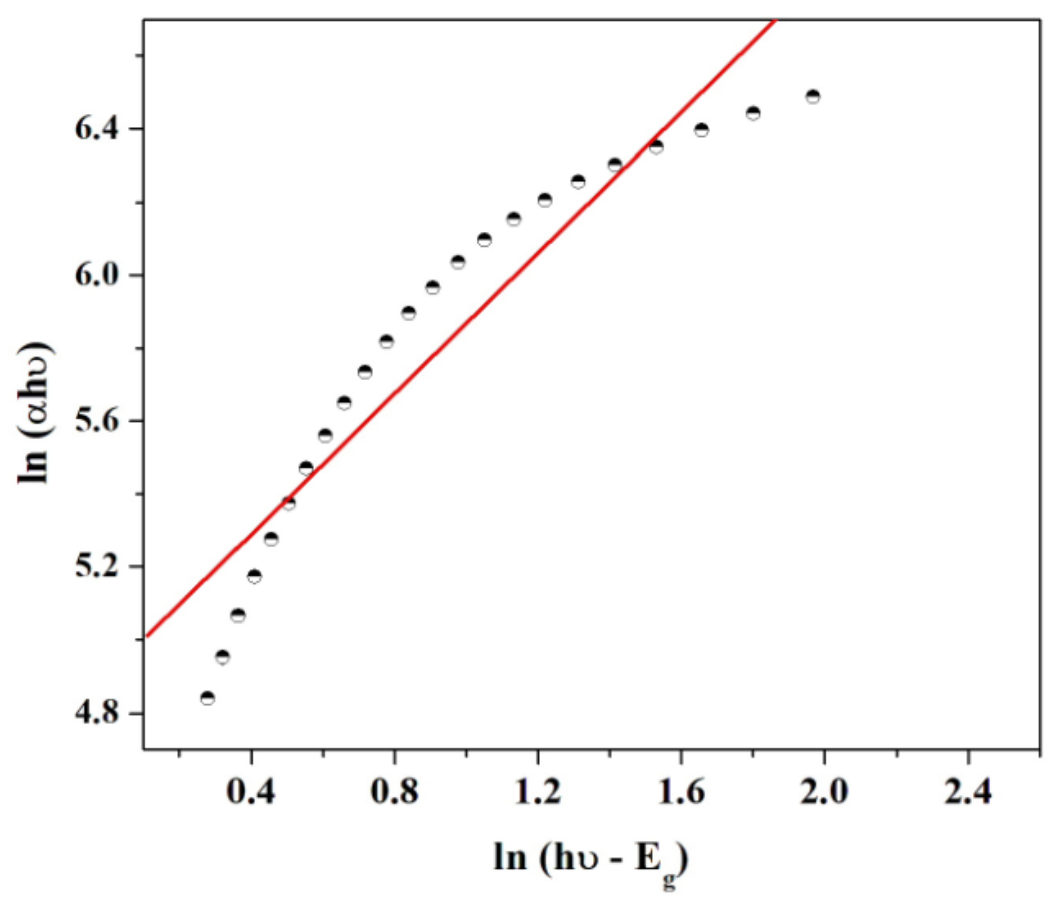

Figure 4. Plot of $\ln \left(h v-E_{g}\right)$ versus $\ln (\alpha h v)$.

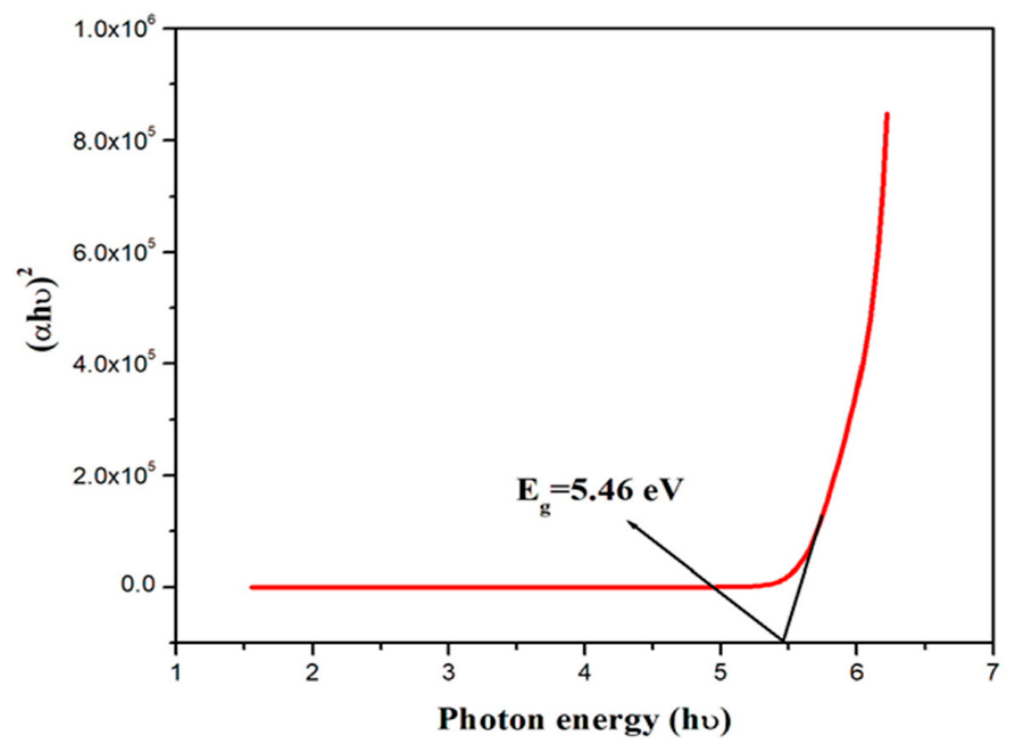

Figure 5. Band gap Spectra-Tauc's Plot.

\subsubsection{Determination of Optical Constants}

Optical characteristics are highly imperative for the materials to identify the adoptability in the fabrication of optoelectronics [20]. The relation of optical absorption coefficient with hu provides knowledge about the band structure of the electron. The $(\alpha)$ was computed using the formula:

$$
\alpha=\frac{2.3026 \log (1 / \mathrm{T})}{\mathrm{t}}
$$

The various optical parameters namely the reflectance $(R)$, the extinction coefficient $(\mathrm{K})$ and the refractive index (n) have been estimated from the formulae (theoretical) [21].

$\mathrm{K}$ is given by:

$$
\mathrm{K}=\frac{\alpha \lambda}{4 \pi}
$$


The reflectance $(\mathrm{R})$ and refractive index $(\mathrm{n})$ can be written as:

$$
\begin{aligned}
& \mathrm{R}=1 \pm \frac{\sqrt{1-\exp (-\alpha \mathrm{t})+\exp (\alpha \mathrm{t})}}{1+\exp (-\alpha \mathrm{t})} \\
& \mathrm{n}=-\left\{\frac{(\mathrm{R}+1) \pm \sqrt{3 \mathrm{R}^{2} 10 \mathrm{R}-3}}{2(\mathrm{R}-1)}\right\}
\end{aligned}
$$

Figure 6 shows the variation of reflectance and extinction coefficient dependence on $\mathrm{h} v$ (photon energy) [21]. The graph (Figure 7) predicts the tied reflectance and extinction coefficient, which enumerates linear values of absorption coefficient and supports its internal capability and potentiality. The photonic response of refractive index (n) shown in Figure 8 illustrates that the refractive index (n) falls with the rise of hv. The sharp optical transparency with a less refractive index of UGA shows its vital property in antireflection coating of solar (thermal) devices [21].
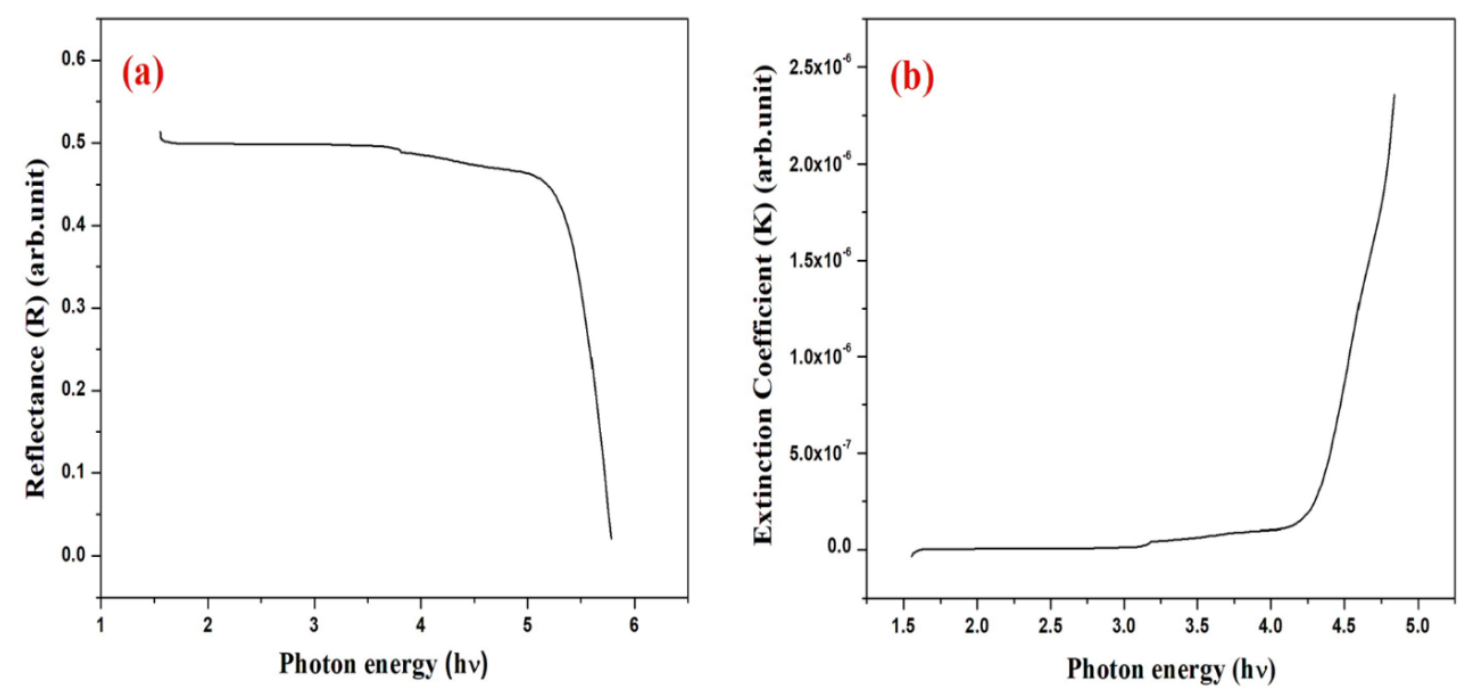

Figure 6. Photonic response of (a) reflectance and (b) extinction coefficient.

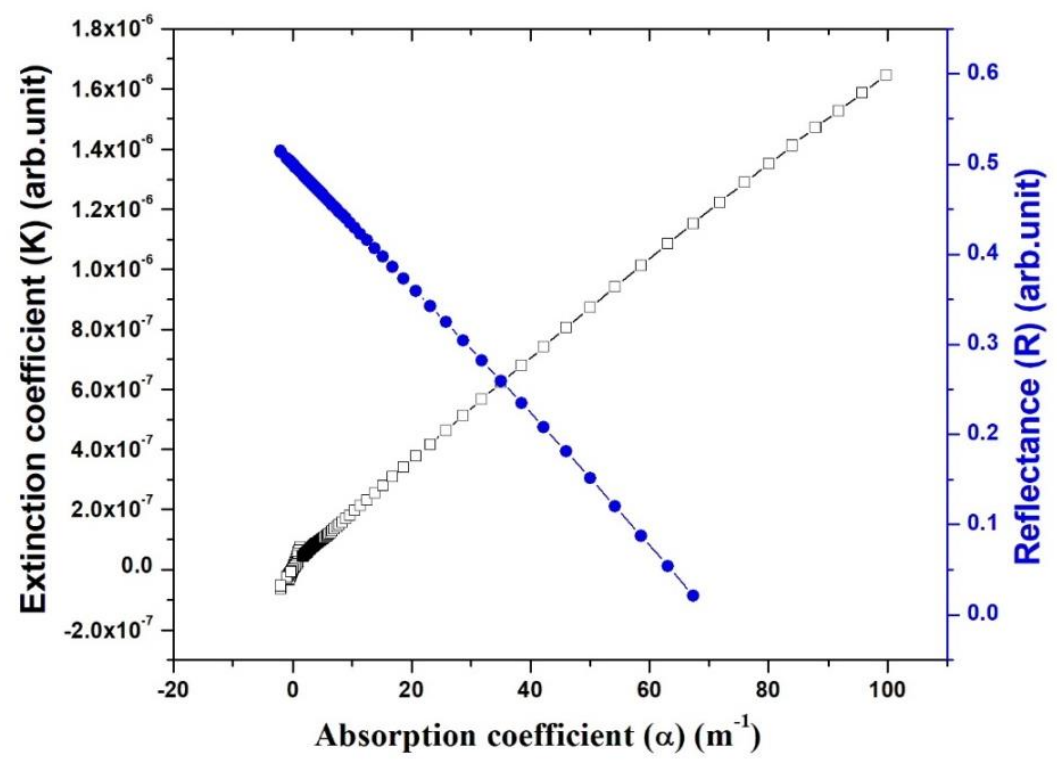

Figure 7. Plot of absorption coefficient versus reflectance and extinction coefficient. 

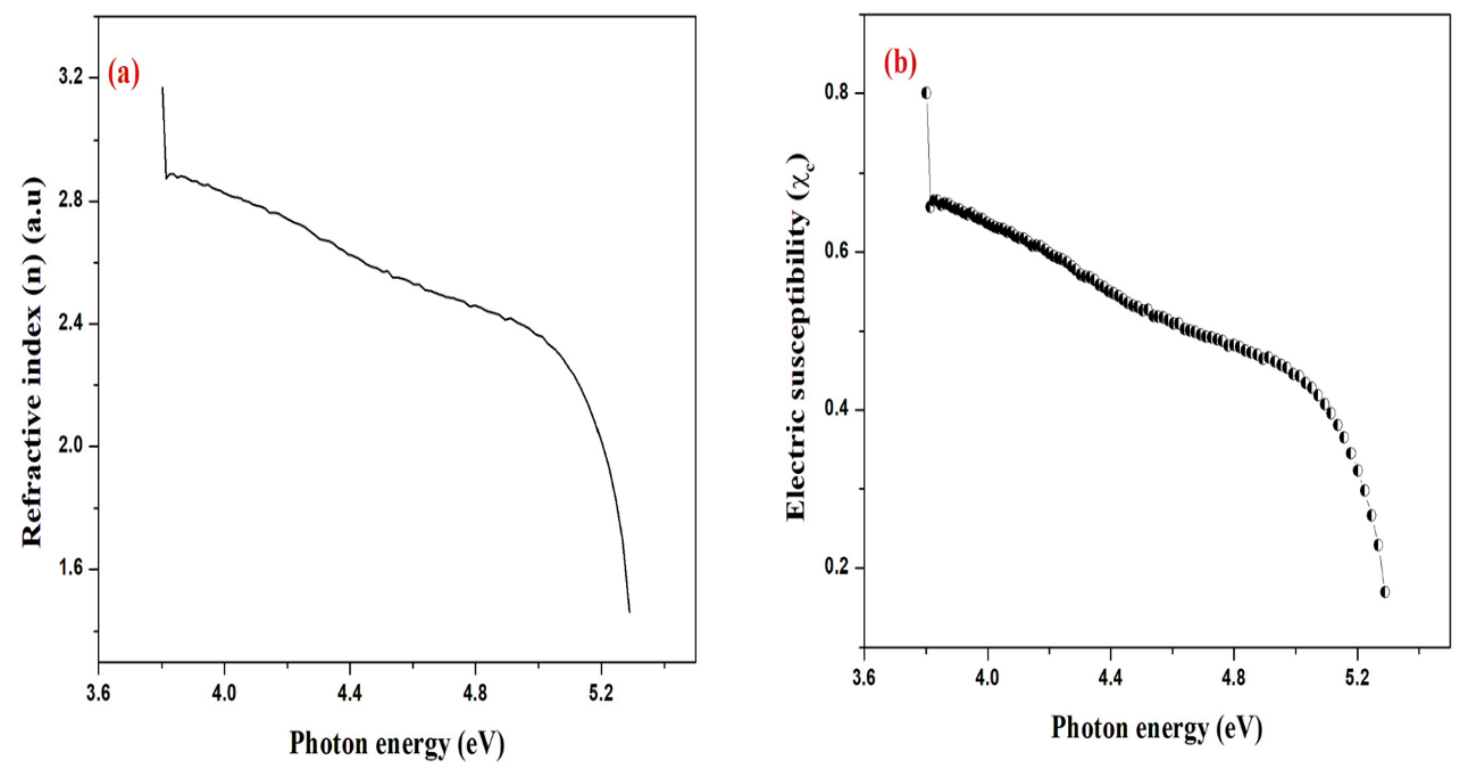

Figure 8. Photon energy versus (a) refractive index and (b) electric susceptibility.

Moreover, the electric susceptibility $\left(\chi_{c}\right)$ of UGA can be estimated as:

$$
\begin{gathered}
\varepsilon_{\mathrm{r}}=\varepsilon_{0}+4 \pi \chi_{\mathrm{c}}=\mathrm{n}_{\mathrm{x}}{ }^{2}-\mathrm{K}^{2} \\
\chi_{\mathrm{c}}=\frac{\mathrm{n}_{\mathrm{x}}{ }^{2}-\mathrm{K}^{2}-\varepsilon_{0}}{4 \pi}
\end{gathered}
$$

\subsubsection{Determination of Absorption Band Tail}

Optical absorption studies play a major part in the domain of material science to show the aptness of the material in photonics. The presence of impurities shows a weak absorption band, the disorder system in the crystal structure shows absorption edge and the optical energy gap shows a strong absorption band. Thus, the presence of absorption coefficient value in close proximity to the band edge reveals an exponential part called Urbach tail. This is very low for good crystalline materials having fewer impurities [22].

Close to the band gap edge, the absorption coefficient is:

$$
\alpha=\alpha_{0} \exp ^{h v / E_{g}}
$$

where $\alpha_{0}$ is the constant and $E_{\mathrm{u}}$ the energy (Urbach) of band tail.

Taking log on both sides of the above expression,

$$
\ln \alpha=\ln \alpha_{0}+\mathrm{hv} / \mathrm{E}_{\mathrm{U}}
$$

Figure 9 clearly illustrates the Urbach or band tail energy from the inverse of the slope to the linear line [23]. For UGA, the Urbach $\left(E_{u}\right)$ was identified to be $0.5450 \mathrm{eV}$. Thus, the variation up to $\pm 0.5 \mathrm{eV}$ is noted for an energy band gap of the grown material. Therefore, the least value confirms UGA has less observed defects and disorder with better purity and good crystalline nature. 


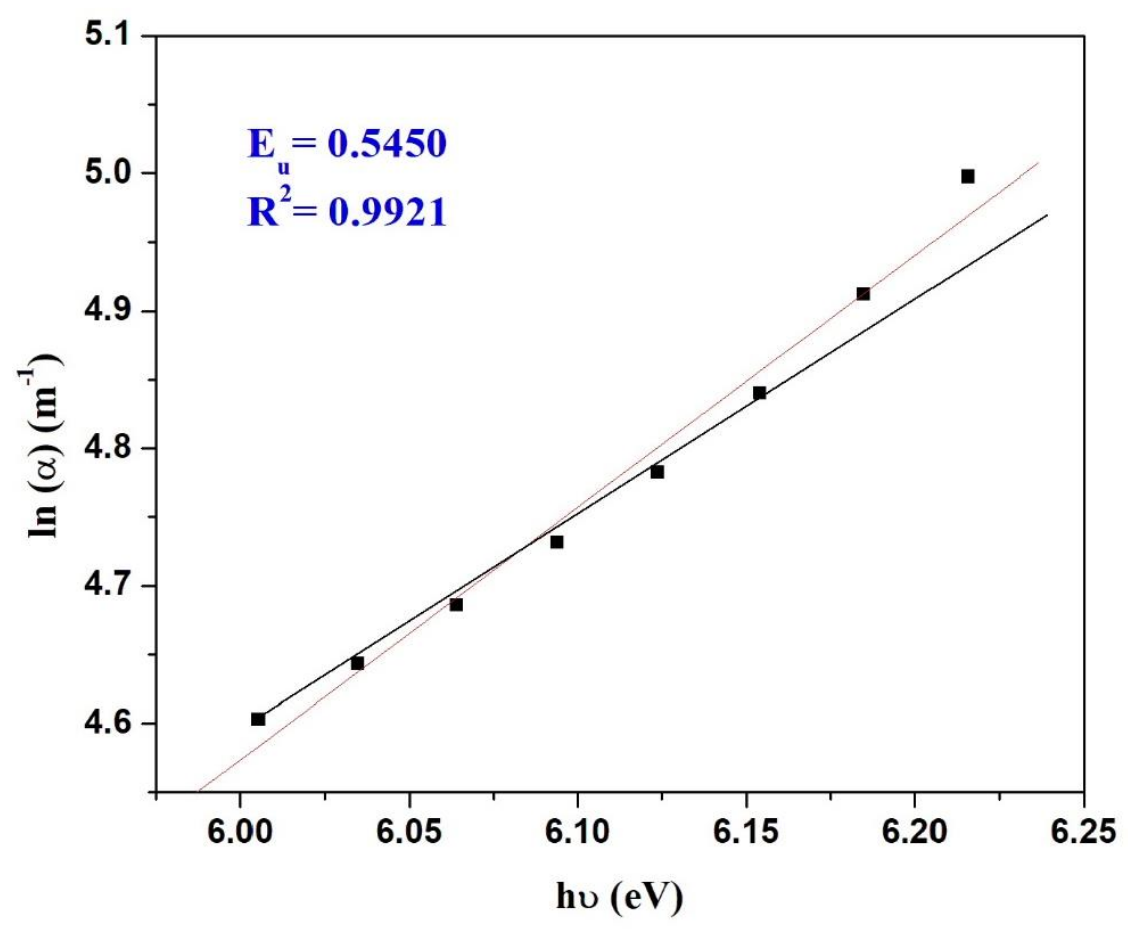

Figure 9. Graph of $\ln (\alpha)$ and hu-Urbach energy.

Urbach recommended another relation combining $(\alpha)$ and $\left(E_{g}\right)$ as:

$$
\alpha=\beta \exp \left\lceil\frac{\sigma(h \vartheta-\mathrm{Eo})}{\mathrm{KT}}\right\rceil
$$

Here, $\beta$ is the pre-exponential constant and $\sigma$ is a steepness parameter. Transition energy Eo should be equal to band gap energy for direct allowed transition.

The steepness parameter can be determined from the formula [14] as:

$$
\sigma=\frac{\mathrm{K}_{\mathrm{B}} \mathrm{T}}{\mathrm{E}_{\mathrm{u}}}
$$

Additionally, the electron-phonon interaction can be determined from the formula [14] as:

$$
\mathrm{E}_{\mathrm{e}-\mathrm{p}=\frac{2}{3 \sigma}}
$$

For the grown UGA, the steepness parameter was calculated as 0.5985 and electronphonon interaction was 1.114. The other optical parameters calculated are tabulated below (Table 2).

Table 2. Calculated optical parameters of UGA.

\begin{tabular}{cc}
\hline Optical Parameters-Report & Calculated Values of UGA \\
\hline$\lambda_{\text {Cutoff }}(\mathrm{nm})$ & $240 \mathrm{~nm}$ \\
\hline $\mathrm{E}_{\mathrm{g}}$ (Band gap) in $\mathrm{eV}$ & $5.46 \mathrm{eV}$ \\
\hline $\mathrm{E}_{\mathrm{u}}($ Urbach energy) in $\mathrm{eV}$ & $0.545 \mathrm{eV}$ \\
\hline Steepness parameter $(\sigma)$ & 0.5985 \\
\hline Electron-phonon interaction $\left(\mathrm{E}_{\mathrm{e}-\mathrm{p}}\right)$ & 1.114 \\
\hline
\end{tabular}




\subsubsection{Determination of the Point of Valence Band and Conduction Band}

Calculated electron affinity along with ionization energy data of the elements of the compound UGA were determined. UGA has 7 carbon atoms, 16 hydrogen atoms, 4 nitrogen atoms, and 6 oxygen atoms. These numbers of atoms of the elements are shown as $\mathrm{i}, \mathrm{j}, \mathrm{k}$ and $\mathrm{m}$. The point of conduction band can be estimated using the formula [24,25]:

$$
\mathrm{E}_{\mathrm{CB}}=\mathrm{E}^{\mathrm{e}}-\mathrm{X}+\frac{\mathrm{E}_{\mathrm{g}}}{2}
$$

where $\mathrm{E}_{\mathrm{CB}}$ is the conduction band position, $\mathrm{E}^{\mathrm{e}}$ is the dissociation energy of $\mathrm{H}_{2}$ molecule, and $X$ is the energy parameter [26]. The calculated positions are tabulated in Table 3 and are represented in Figure 10.

Table 3. Positions of conduction band, valence band and energy gap.

\begin{tabular}{ccc}
\hline $\begin{array}{c}\text { Electron Affinity } \\
\left(\mathrm{E}_{\mathbf{A}} \text { in } \mathbf{~}\right)\end{array}$ & $\begin{array}{c}\text { Ionisation Energy } \\
\left(\mathrm{E}_{\mathbf{I}} \text { in } \mathbf{~}\right)\end{array}$ & Positions of $\mathrm{E}_{\mathrm{CB}}, \mathrm{E}_{\mathrm{VB}}$ and $\mathrm{E}_{\mathbf{g}}$ in $\mathbf{~ V V}$ \\
\hline $\mathrm{C}-1.262$ & $\mathrm{C}-11.2603$ & -0.86 \\
\hline $\mathrm{H}-0.754$ & $\mathrm{H}-13.5984$ & 4.6 \\
\hline $\mathrm{N}--1.4$ & $\mathrm{~N}-14.5341$ & 5.46 \\
\hline $\mathrm{O}-1.461$ & $\mathrm{O}-13.6181$ & \\
\hline
\end{tabular}

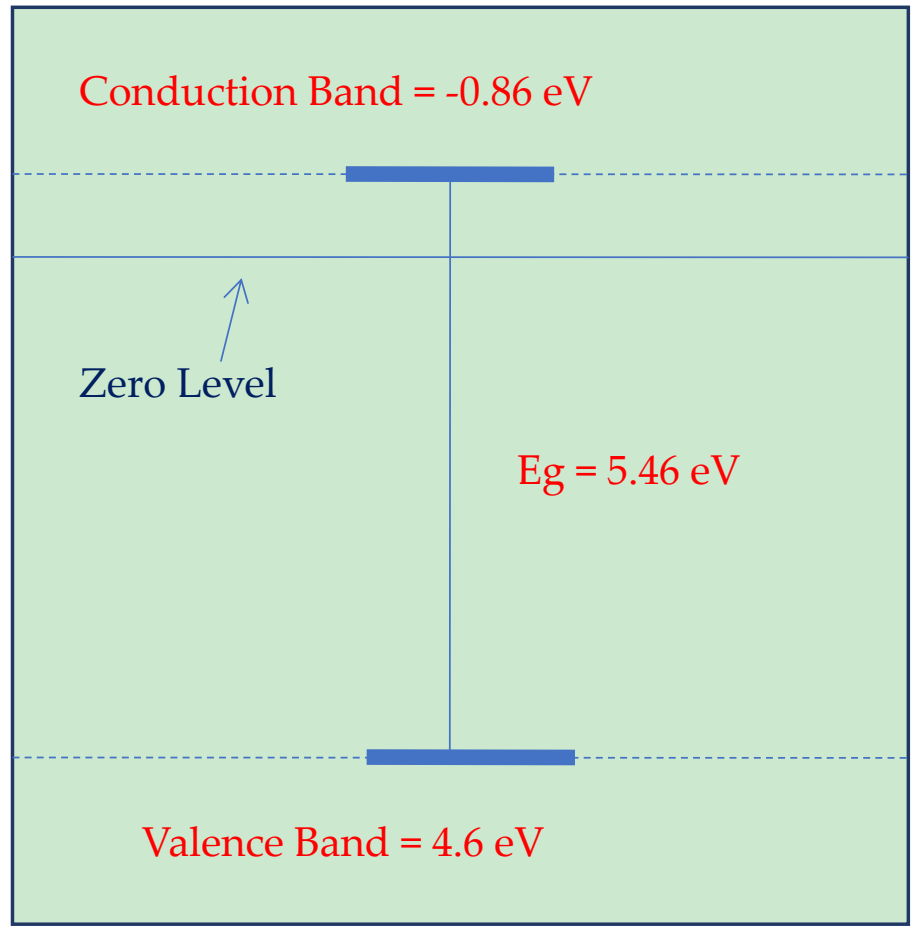

Figure 10. Position of conduction band and valence band of UGA.

\subsection{Determination of Plasma Energy, Penn Gap Energy, Fermi Energy and Polarizabilty}

The electronic polarizability $(\alpha)$ is notable for finding efficiency of nonlinear effects of materials. The electro-optic polarizability of the material is purely based on the solid state parameters, which act as an efficient approving method for finding NLO properties [27]. The dielectric permittivity of the material depends on the valence (free) electrons shown in the material. 
The density $(\rho)$ can be found using the formula:

$$
\rho=\frac{\mathrm{MZ}}{\mathrm{N}_{\mathrm{A}} \mathrm{V}}
$$

$\mathrm{M}$ is the molecular weight $\left(252.23 \mathrm{~g} \mathrm{~mol}^{-1}\right), \mathrm{Z}=4$ is the total number of atoms per unit cell, $\mathrm{N}_{\mathrm{A}}$ is the Avogadro number $\left(6.023 \times 10^{23}\right)$ and $\mathrm{V}$ (volume). After calculation, the density was identified to be $1.425 \mathrm{~g} / \mathrm{cm}^{3}$.

The valence electron plasma energy $h \omega_{p}$ is calculated as:

$$
\hbar \omega=28.8\left(\frac{Z^{\prime} * \rho}{M}\right)^{1 / 2}
$$

The sum of valence electrons $Z^{\prime}$ is $Z^{\prime}=\left[\left(7 * Z_{C}^{\prime}\right)+\left(16 * Z_{H}^{\prime}\right)+\left(4 * Z_{N}^{\prime}\right)+\left(6 * Z^{\prime} \mathrm{o}\right)\right]=100$. The dielectric permittivity at $1 \mathrm{MHz}$ was calculated to be 10.93 .

Penn gap energy:

$$
\mathrm{E}_{\mathrm{p}}=\frac{\hbar \omega \mathrm{p}}{(\varepsilon-1)^{1 / 2}}
$$

Fermi energy:

$$
\mathrm{E}_{\mathrm{F}}=0.2948 \hbar \omega \mathrm{p}^{4 / 3}
$$

Polarizability $\left(\alpha_{p}\right)$ can be calculated as:

$$
\alpha_{\mathrm{p}}=\frac{3 \mathrm{M}}{4 \pi \mathrm{N} \rho} * \frac{\varepsilon_{\infty}-1}{\varepsilon_{\infty}+2}
$$

The electronic polarizability due to band gap $\mathrm{E}_{\mathrm{g}}$ is given as:

$$
\alpha=\left[1-\frac{\sqrt{E_{g}}}{4.06}\right] * \frac{M}{\rho} * 0.396 * 10^{-24} \mathrm{~cm}^{3}
$$

Using the above mentioned relations, solid state parameters were tabulated (Table 4). This clears the supporting factor for NLO efficiency of the crystal [27].

Table 4. Calculated parameters of UGA.

\begin{tabular}{ccc}
\hline Solid State Parameters (eV) & Calculated Values (eV) & Values of KDP \\
\hline Plasma Energy & 21.6472 & 17.28 \\
\hline Penn gap energy & 6.873 & 2.37 \\
\hline Fermi Energy & 17.77 & 12.02 \\
\hline Polarizability by Clausius-Mossotti relation & $5.3896 \times 10^{-23} \mathrm{~cm}^{3}$ & $2.10 \times 10^{-23} \mathrm{~cm}^{3}$ \\
\hline
\end{tabular}

\subsection{Hardness Studies}

The hardness of the material is considered most essential in standardizing the ability of the crystal in the fabrication of optoelectronics. The mechanical ability (strength) was found by using the Vickers micro hardness test for cutting and polishing the crystal [28]. In order to enhance the strength of the grown crystal, the hardness test was estimated by Vickers micro hardness tester. The extremely transparent crystals are viewed on indentations with the load ranging from 25 to $100 \mathrm{gm}$ with a time of $10 \mathrm{sec}$. Surface defects of UGA are avoided by choosing the gap between successive indentations and placing them higher than five times the length (diagonally). The Vickers hardness value $\left(\mathrm{H}_{\mathrm{v}}\right)$ was evaluated as [28]:

$$
\mathrm{H}_{\mathrm{v}}=1.8544 \frac{\mathrm{P}}{\mathrm{d}^{2}}\left(\mathrm{~kg} / \mathrm{mm}^{2}\right)
$$


Here, 1.8544 is a geometrical factor, $\mathrm{d}$ indicates the length (diagonal) and $\mathrm{P}$ represents the load (applied). Figure 11a shows that the hardness $\left(\mathrm{H}_{\mathrm{V}}\right)$ of the crystal increases drastically with an increase of the load (applied), validating high mechanical potency of the UGA crystal. The correlation between the load (applied) and the indentation range can be constituted by:

$$
\mathrm{P}=\mathrm{Kd} \mathrm{d}^{\mathrm{n}}
$$
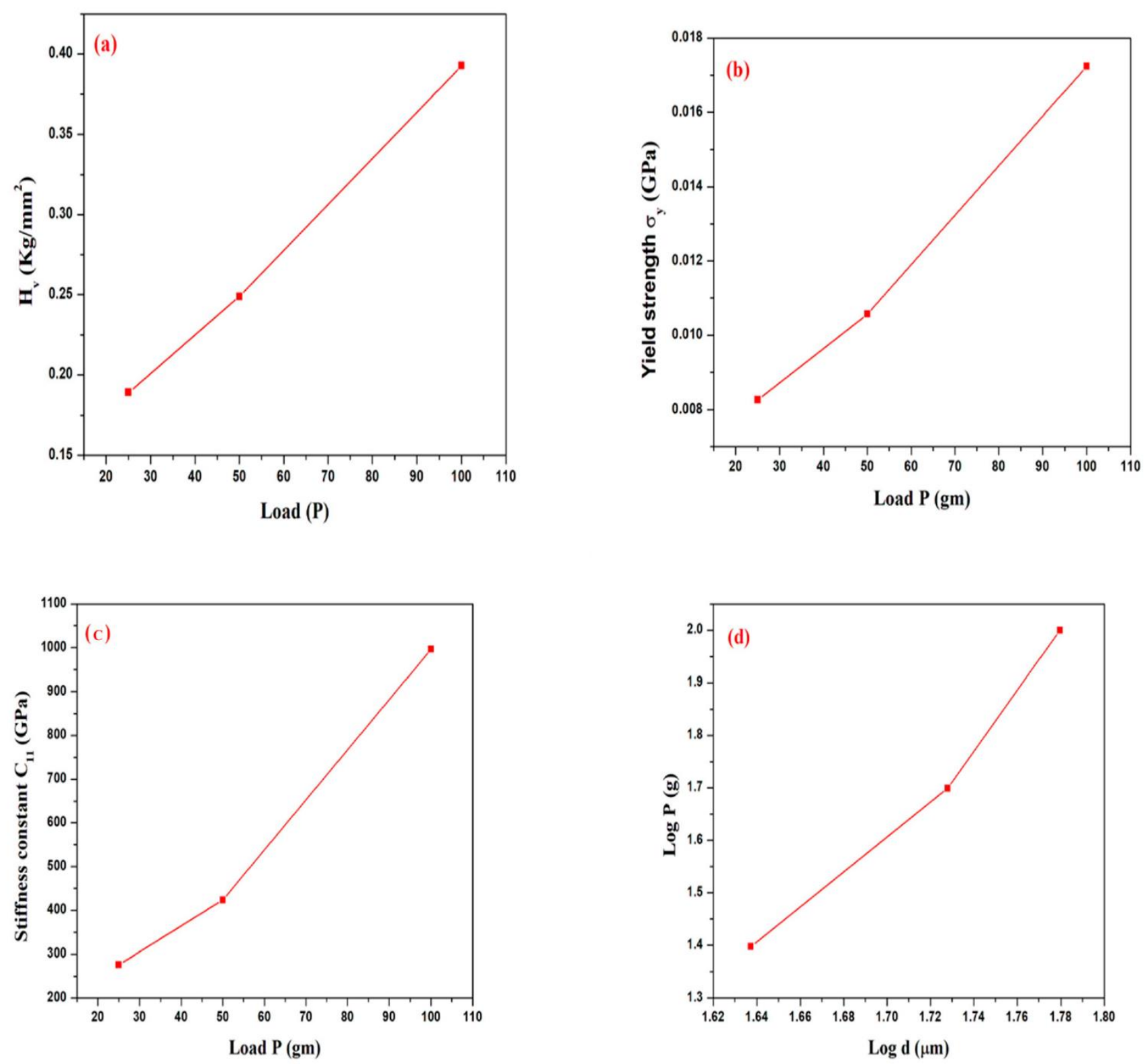

Figure 11. (a) Hardness number, (b) yield strength, (c) stiffness constant, and (d) log d versus $\log P$.

$\mathrm{K}$ (constant) and $\mathrm{n}$ the Meyer's index. The slope value from Figure 11 declares work hardening coefficient as $(\mathrm{n}=4.12)$ and highlights that the grown UGA belongs to soft category material [29].

The elastic stiffness constant $\left(C_{11}\right)$ is determined using Wooster's empirical formula [30]:

$$
\mathrm{C}_{11}=\left(\mathrm{H}_{\mathrm{v}}\right)^{7 / 4}
$$


$\mathrm{C}_{11}$ predicts an assessment of bonding to the closest atoms. The variation of load $\mathrm{P}$ (applied) versus $C_{11}$ is represented in Figure 11c. Thus, the graph affirms the stiffness constant rises rapidly with the increase of the load (applied). The greater value of $C_{11}$ predicts the strong binding forces to the ions.

The yield strength $\left(\sigma_{\mathrm{y}}\right)$ can be evaluated as:

$$
\sigma_{\mathrm{y}}=\frac{\mathrm{H}_{\mathrm{v}}}{3}(0.1)^{\mathrm{n}^{\prime}-2}
$$

Here, $\mathrm{H}_{\mathrm{v}}$ is the hardness value and $\mathrm{n}$ specifies Meyer's index value. A graph between load P (applied) vs. yield strength $\sigma_{\mathrm{y}}$ is represented in Figure 11b. The Knoop hardness test is used to identify the brittleness of the materials.

The Knoop hardness number $\left(\mathrm{H}_{\mathrm{k}}\right)$ is formulated as [29]:

$$
\mathrm{H}_{\mathrm{k}}=14.229 \frac{\mathrm{P}}{\mathrm{d}^{2}}\left(\mathrm{~kg} / \mathrm{mm}^{2}\right)
$$

Here, P stands for the load (applied) in gm, while $\mathrm{d}$ represents the length (diagonal). The calculated Knoop number for various loads is presented in Table 5 to identify the brittleness of the grown crystal. The variation between load $\mathrm{P}$ (applied) and $\mathrm{H}_{\mathrm{k}}$ is illustrated in Figure 11d.

\begin{tabular}{|c|c|c|c|c|}
\hline $\begin{array}{c}\text { Load P }(\mathrm{g}) \\
\text { Knoop Hardness } \\
\text { Number } \mathrm{H}_{\mathrm{k}}\end{array}$ & $\mathrm{H}_{\mathrm{v}}\left(\mathrm{kg} \mathrm{mm}^{-2}\right)$ & $\sigma_{y}(\mathrm{GPa})$ & $\mathrm{C}_{11}(\mathrm{GPa})$ & $\mathrm{H}_{\mathrm{k}}\left(\mathrm{kg} \mathrm{mm}^{-2}\right)$ \\
\hline 25 & 24.8 & 8.267 & 2.756 & 18.90 \\
\hline 50 & 31.7 & 10.567 & 4.235 & 24.90 \\
\hline 100 & 51.7 & 17.233 & 9.968 & 39.26 \\
\hline
\end{tabular}

Table 5. Mechanical characteristics of UGA.

The calculated mechanical parameters of UGA support the hardness of the material and the data are presented and tabulated in Table 5.

\subsubsection{Knoop Hardness Number}

Knoop hardness analysis identifies the brittleness of the material. The Knoop hardness number is formulated from [29]:

$$
\mathrm{H}_{\mathrm{k}}=14.229 \frac{\mathrm{P}}{\mathrm{d}^{2}}\left(\mathrm{~kg} / \mathrm{mm}^{2}\right)
$$

Here P represents the load $(\mathrm{gm})$ and $\mathrm{d}$ represents length (diagonal $\mathrm{mm}$ ). The calculated Knoop hardness number for three applied loads is presented in Table 6 to show the brittleness of the grown crystal. The variation in $\mathrm{P}$ (applied) and Knoop number $\mathrm{H}_{\mathrm{k}}$ is illustrated in Figure 12.

Table 6. Calculated Knoop hardness number for different loads of UGA.

\begin{tabular}{cc}
\hline Load $\mathbf{P}(\mathbf{g})$ & Knoop Hardness Number $\mathbf{H}_{\mathbf{k}}$ \\
\hline 25 & 18.90 \\
50 & 24.90 \\
100 & 39.26 \\
\hline
\end{tabular}




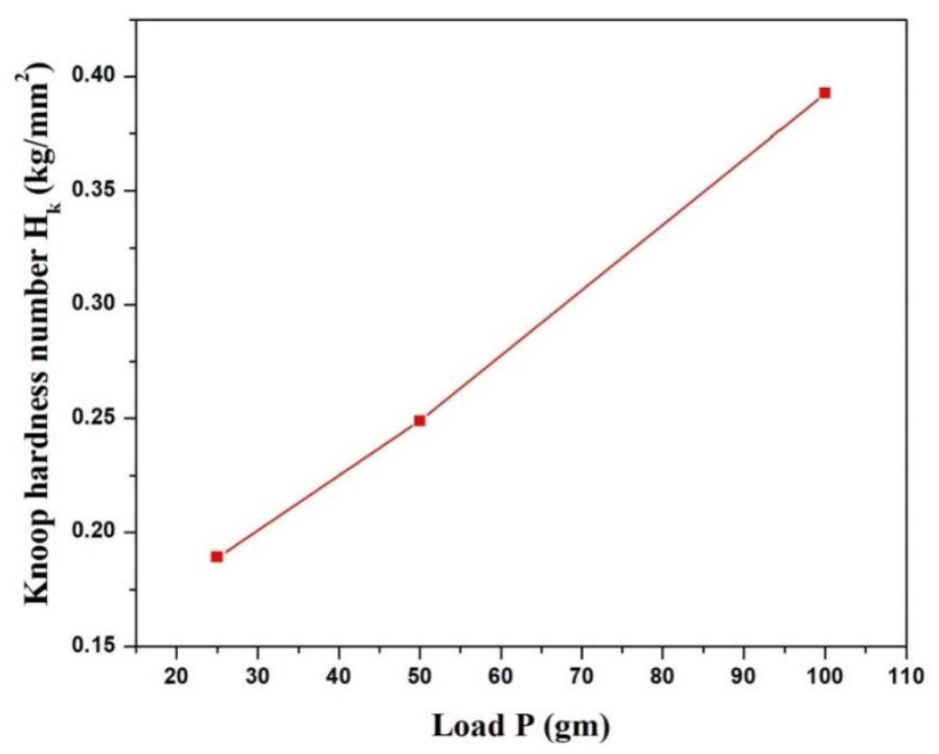

Figure 12. Load $P$ with Knoop hardness number.

\subsubsection{Hays-Kendall (HK) Approach}

The indentation size effect (ISE) of materials was proposed by Hays and Kendall [31], and indicates the strong or weak behavior of indentation for UGA.

$$
\mathrm{P}=\mathrm{W}+\mathrm{A}_{1} \mathrm{~d}^{\mathrm{n}}
$$

where $\mathrm{W}$ is the bare minimum load and $\mathrm{A}_{1}$ is a constant with $\mathrm{n}=4.12$. The graph (Figure 13) is plotted between load $\mathrm{P}$ and $\mathrm{d}^{2}$, evaluating $\mathrm{W}$ and $\mathrm{A}_{1}$. Considering the negative resistance pressure, the crystal exhibits strong reverse ISE nature for a UGA crystal. The corrected load, which is not depending on $\mathrm{H}_{\mathrm{HK}}$, can be estimated from [32],

$$
\mathrm{H}_{\mathrm{HK}}=1854.4 \mathrm{~A}_{1}
$$

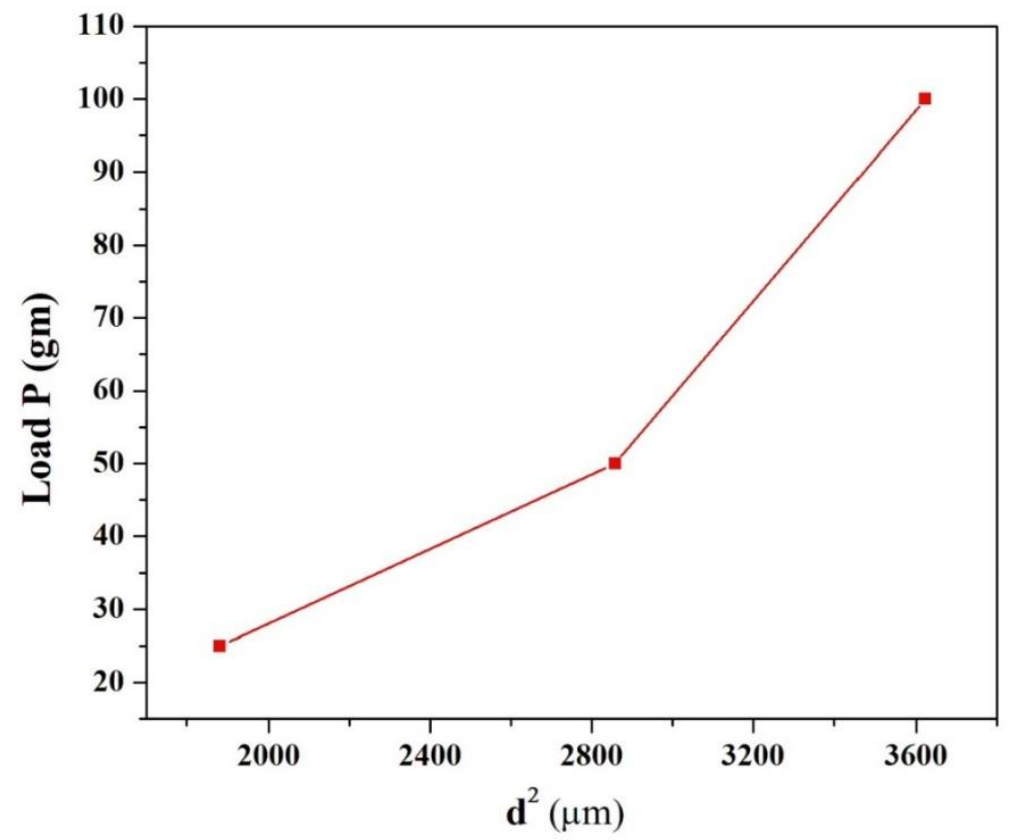

Figure 13. Variation of $\mathrm{d}^{2}$ versus Load P for UGA. 
The estimated values are specified and tabulated (Table 7).

Table 7. Calculated $\mathrm{HK}$ constant $\mathrm{W}, \mathrm{A}_{1}$ and $\mathrm{H}_{\mathrm{HK}}$ for UGA.

\begin{tabular}{cc}
\hline Constant (Hays-Kendell) & Calculated Outcomes \\
\hline Resistance pressure $(\mathrm{W})$ & $-59.51(\mathrm{~g})$ \\
Load independent constant $\left(\mathrm{A}_{1}\right)$ & $0.042 \mathrm{~g} / \mathrm{mm}^{2}$ \\
Corrected load independent hardness $\left(\mathrm{H}_{\mathrm{HK}}\right)$ & $77.88 \mathrm{~g} / \mathrm{\mu m}^{2}$ \\
\hline
\end{tabular}

\subsection{Determination of Non Linear Optical Studies}

The NLO is an important parameter for organic, inorganic and semi-organic materials to show its optical alertness in the domain of photonics, optoelectronics, communications (optical), laser development, etc. The grown organic material UGA was thoroughly analyzed to undergo second harmonic generation process by the Kurtz-Perry method [33]. The material was finely powdered and a high beam Nd-YAG laser $(1064 \mathrm{~nm})$ made to pass through the material with sample material as KDP. The SHG output shows no green light emission. Even though UGA belongs to centrosymmetric crystal, it exhibits the absence of green light emission and hence second order nonlinearity is absent.

The nonlinear property of the material was proved by extending UGA to third order harmonic generation studies (Z-scan). This was employed using Nd-YAG laser (Coherent compass TM215M-50) with $532 \mathrm{~nm}$ to show third order nonlinearities. The Z-scan method is an accurate and simple method for determining nonlinear absorption and refraction to prove the nonlinearity of the compound. The result verifies better nonlinear optical characteristics and its nonlinear absorption and refraction are dispensed to the negative nonlinearity and the two-photon absorption process. The change in the refractive index with the rise in temperature leads to self-defocusing nature, which shows evidence from the negative nonlinear variation. The closed aperture configuration is gentler in yielding nonlinear absorption and refraction. The observed peak followed by the valley configuration in Figure 14 illustrates the negative nonlinearity, which is attributed to self-defocusing nature [18]. In the open aperture configuration, the transmittance curve shown in Figure 14 is symmetric with respect to focus and shows the two-photon absorption process [21]. This shows its efficiency over possible recognition of signal processing devices in optics [34].
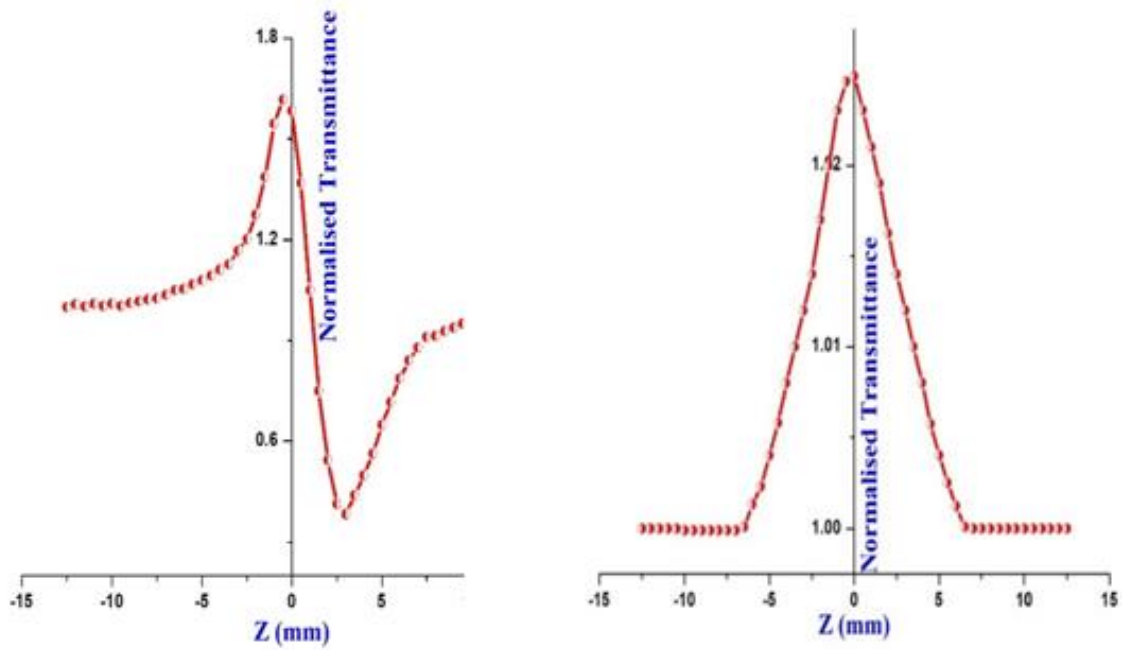

Figure 14. Closed and open aperture of UGA.

Hence, the nonlinear refractive index $\left(\mathrm{n}_{2}\right)$ and $(\beta)$ was calculated to be $7.80 \times 10^{-8} \mathrm{~cm}^{2} / \mathrm{W}$ and $0.02 \times 10^{-4} \mathrm{~cm} / \mathrm{W}$ respectively. The absolute susceptibility $\left|\chi^{(3)}\right|$ was identified to be $8.54 \times 10^{-6} \mathrm{esu}$. This was clearly and elaborately reported in our previous work [13]. The calculated values of $\mathrm{n}_{2}$ showed self-defocusing behavior of the crystal, which exhibits 
nonlinear optical properties. The $\beta$ value showed its saturable absorption behavior, which is highly useful in optical limiting applications [21].

\section{Conclusions}

The optical properties were examined both experimentally and theoretically for the organic material, urea glutaric acid (UGA), which was synthesized at a low temperature. Single crystal XRD confirms the monoclinic structure with $\mathrm{C} 2 / \mathrm{c}$ space group. The cell parameters are observed and compared with the reported work. The transmittance graph shows the low cutoff wavelength as $240 \mathrm{~nm}$, with an energy gap identified to be $5.46 \mathrm{eV}$. This is verified theoretically and found to be $5.175 \mathrm{eV}$. The diverse optical parameters were calculated and the results support good nonlinearity for optical applications. The low Urbach energy $(0.545 \mathrm{eV})$ provides support for fewer defects with less impurities and better crystalline nature. The steepness parameter (0.5985) and electron phonon interaction (1.114) was calculated. The electron transition from valence band and conduction band is a direct allowed transition, which is found from transition number $(0.462 \mathrm{eV})$. The position of lower and higher energy band is also determined from the electron affinity and ionization energy of the molecules present in UGA. Electronic polarizability was calculated using the Clausius-Mossoti relation $\left(5.3896 \times 10^{-23} \mathrm{~cm}^{3}\right)$ and tabulated. The mechanical stability was measured from Vickers hardness analysis. From the Z-scan data nonlinear refractive index $\left(\mathrm{n}_{2}\right) 7.80 \times 10^{-8} \mathrm{~cm}^{2} / \mathrm{W}$, absorption coefficient $(\beta) 0.02 \times 10^{-4} \mathrm{~cm} / \mathrm{W}$ was calculated and the susceptibility was identified to be $8.54 \times 10^{-6}$ esu. The various optical parameters from third harmonic generation studies show UGA as an efficient material over device fabrication in nonlinear optics.

Author Contributions: Conceptualization, C.R.T.K.; A.A.O. and T.K.; methodology, M.N.; software, G.M.; formal analysis, A.M.; investigation, M.L.C.; resources, S.S.; H.A.K.; P.M. data curation, A.K.; writing-original draft preparation, C.R.T.K.; writing—review and editing, A.M.; visualization, A.M.A.; supervision, H.M.M.; project administration, T.K.; funding acquisition, A.K. All authors have read and agreed to the published version of the manuscript.

Funding: The Deanship of Scientific Research (DSR) at King Abdulaziz University, Jeddah Saudi Arabia has funded this project, under grant number (KEP-42-130-42).

Acknowledgments: The Deanship of Scientific Research (DSR) at King Abdulaziz University, Jeddah Saudi Arabia has funded this project, under grant number (KEP-42-130-42). The authors acknowledge the absolute support extended for this research work by SAIF, IIT Madras Chennai, St. Peter's University, Chennai, St. Joseph College Trichirapalli, Vellore Institute of Technology, Chennai Campus.

Conflicts of Interest: The authors declare no conflict of interest.

\section{References}

1. Nandhini, S.; Murugakoothan, P. Growth and characterization of a novel organic nonlinear optical crystal guanidinium 4hydroxybenzoate: Potential candidate for optoelectronic applications. Mater. Lett. 2019, 241, 152-155. [CrossRef]

2. Kumari, C.R.T.; Nageshwari, M.; Jayaprakash, P.; Sangeetha, P.; Sudha, S.; Caroline, M.L. Investigation on growth, optical, thermal, mechanical, dielectric, LDT studies of sulphanilic acid monohydrate: A promising third order nonlinear optical material. J. Nonlinear Opt. Phys. Mater. 2017, 26, 1750020. [CrossRef]

3. Kandan, S.; Krishnan, P.; Jagan, R.; Aravindhan, S.; Srinivasan, S.; Gunasekaran, S. Structural, optical and piezoelectric investigation on new Brucinium Chlorate di hydrate NLO single crystal for opto electronic, piezo-sensor, transducer and OLED applications. Opt. Mater. 2018, 84, 556-563. [CrossRef]

4. Jagadeesh, M.R.; Kumar, H.S.; Kumari, R.A. Crystal growth and characterization of a new crystal: Urea 2 Furoic acid. Optik 2015, 126, 4014-4018. [CrossRef]

5. Senthilkumar, C.; Rajesh, P.; Ramasamy, P. Crystal growth, structural, optical, thermal and dielectric properties of lithium hydrogen oxalate monohydrate single crystal. Opt. Mater. 2017, 73, 154-162.

6. Ha, J.M.; Hamilton, B.D.; Hillmyer, M.A.; Ward, M.D. Phase behavior and polymorphism of organic crystals confined within nanoscale chambers. Cryst. Growth Des. 2009, 9, 4766-4777. [CrossRef]

7. Rao, A.S.; Dar, M.H.; Venkatramaiah, N.; Venkatesan, R.; Sharan, A. Third order optical nonlinear studies and its use to estimate thickness of sandwiched films of tetra-phenyl porphyrin derivatives. J. Nonlinear Opt. Phys. Mater. 2016, 25, 1650039. [CrossRef] 
8. Janczak, J.; Perpétuo, G.J. Melaminium glutarate monohydrate. Acta Crystallogr. Sect. C Cryst. Struct. Commun. 2002, 58, 339-341. [CrossRef]

9. Dhavamurthy, M.; Peramaiyan, G.; NizamMohideen, M.; Kalainathan, S.; Mohan, R. Structural, growth and optical characterizations of an organic third-order nonlinear crystal: Guanidiniumtrichloroacetate. J. Nonlinear Opt. Phys. Mater. 2015, 24, 1550045. [CrossRef]

10. Riscob, B.; Shakir, M.; Sundar, J.K.; Natarajan, S.; Wahab, M.A.; Bhagavannarayana, G. Synthesis, growth, crystal structure and characterization of a new organic material: Glycine glutaric acid, Spectrochim. Acta. A Mol. Biomol. Spectrosc. 2010, 78, 543-548. [CrossRef]

11. Jayaprakash, R.N.; Kumaradass, P. Growth and characterization of Urea L-valine, an organic nonlinear optical single crystal. Orient. J. Chem. Int. Res. J. Pure Appl. Chem. 2013, 29, 4.

12. Videnova-Adrabinska, V. Pre-designed Structural Building Blocks of a (1:1) Urea-Glutaric. Acid Co-crystal. J. Mater. Chem. 1995, 5, 2309-2311. [CrossRef]

13. Kumari, C.R.; Sudha, S.; Vinitha, G.; Nageshwari, M.; Caroline, M.L.; Mathubala, G.; Manikandan, A. Synthesis and characterization analyses of unique organic crystal-Urea Glutaric acid, an optimistic candidate for optical applications. Phys. B Phys. Condens. Matter 2020, 577, 411804. [CrossRef]

14. Karuppasamy, P.; Pandian, M.S.; Ramasamy, P.; Verma, S. Crystal growth, structural, optical, thermal, mechanical, laser damage threshold and electrical properties of triphenylphosphine oxide 4-nitrophenol (TP4N) single crystals for nonlinear optical applications. Opt. Mater. 2018, 79, 152-171. [CrossRef]

15. Murugesan, V.; Saravanabhavan, M.; Sekar, M. Synthesis, characterization and pharmacological investigation of a new chargetransfer complex of 3-aminopyridinum-p-toluenesulfonate. J. Mol. Struct. 2015, 1084, 95-102. [CrossRef]

16. Gunasekaran, S.; Anand, G.; ArunBalaji, R.; Dhanalakshmi, J.; Kumaresan, S. Crystal growth and comparison of vibrational and thermal properties of semi-organic nonlinear optical materials, Indian Academy of science. PRAMANA J. Phys. 2010, 75, 683-690. [CrossRef]

17. Chopra, N.; Mansingh, A.; Chadha, G.K. Electrical, optical and structural properties of amorphous $\mathrm{V}_{2} \mathrm{O}_{5}-\mathrm{TeO}_{2}$ blown films. J. Cryst. Solids 1990, 126, 194-201. [CrossRef]

18. Tauc, J. (Ed.) Amorphous and Liquid Semiconductors; Plenum: New York, NY, USA, 1974.

19. Gupta, R.K.; Cavas, M.; Yakuphanoglu, F. Structural and optical properties of nanostructure CdZnO films. Spectrochim. Acta Part A Mol. Biomol. Spectrosc. 2012, 95, 107-113. [CrossRef] [PubMed]

20. Azhar, S.M.; Anis, M.; Hussaini, S.S.; Kalainathan, S.; Shirsat, M.D.; Rabbani, G. Doping effect of L-cystine on structural, UV-visible, SHG efficiency, third order nonlinear optical, laser damage threshold and surface properties of cadmium thiourea acetate single crystal. Opt. Laser Technol. 2017, 87, 11-16. [CrossRef]

21. LathaMageshwari, P.S.; Priya, R.; Krishnan, S.; Joseph, V.; Das, S.J. Growth, optical, thermal, mechanical and dielectric studies of sodium succinate hexahydrate ( $\beta$ phase) single crystal: A promising third order NLO material. Opt. Laser Technol. 2016, 85, 66-74. [CrossRef]

22. Ikhmayies, S.J.; Ahmad-Bitar, R.N. A study of the optical bandgap energy and Urbach tail of spray-deposited CdS:In thin films. J. Mater. Res. Technol. 2013, 2, 221-227. [CrossRef]

23. Urbach, F. The long-wavelength edge of photographic sensitivity and of the electronic absorption of solids. Phys. Rev. 1953, 92, 1324. [CrossRef]

24. Xing, C.; Zhang, Y.; Yan, W.; Guo, L. Band Structure-Controlled Solid Solution of $\mathrm{Cd}_{1-\mathrm{x}} \mathrm{Zn}_{\mathrm{x}} \mathrm{S}$ photocatalyst for hydrogen production by water splitting. Int. J. Hydrog. Energy 2006, 31, 2018-2024. [CrossRef]

25. Askari, M.; Soltani, N.; Saion, E.; Yunus, W.M.M.; Erfani, H.M.; Dorostkar, M. Structural and optical properties of PVP-capped nanocrystalline $\mathrm{Zn}_{\mathrm{x}} \mathrm{Cd}_{1-\mathrm{x}} \mathrm{S}$ solid solutions. Superlattices Microstruct. 2015, 81, 193-201. [CrossRef]

26. Herzberg, G.; Monfils, A. The dissociation energies of the $\mathrm{H}_{2}, \mathrm{HD}$, and $\mathrm{D}_{2}$ molecules. J. Mol. Spectrosc. 1961, 5, 482-498. [CrossRef]

27. Castañón-Alonso, S.L.; Morales-Saavedra, O.G.; Báez-Pimiento, S.; Ortega-Martínez, R.; Rodríguez-Rosales, A.A.; HernándezRojas, M.E. Synthesis and overall nonlinear optical characterization of poly (hexa-2, 4-diynylen-1, 6-dioxydibenzoate) containing 2, 2'-(4-((4-nitrophenyl) ethynyl) phenylazanediyl) diethanol. Mater. Chem. Phys. 2012, 133, 528-540. [CrossRef]

28. Karan, S.; Gupta, S.P.S. Vickers micro hardness studies on solution-grown single crystals of magnesium sulphatehepta-hydrate. Mater. Sci. Eng. 2005, 398, 198-203. [CrossRef]

29. Sangwal, K.; Kothari, A.; Arora, S.K. Surface diffraction structure determination from combinatorial simultaneous optimization. Surf. Sci. 2006, 600, 1475-1486. [CrossRef]

30. Wooster, W.A. Physical properties and atomic arrangements in crystals. Rep. Prog. Phys. 1953, 16, 62-82. [CrossRef]

31. Hays, C.; Kendall, E.G. An analysis of Knoopmicrohardness. Metallography 1973, 6, 275-282. [CrossRef]

32. Cavdar, S.; Deniz, E.; Koralay, H.; Ozturk, O.; Erdem, M.; Gunen, A. The Effect of PbSe Addition on the Mechanical Properties of Bi-2212 Superconductors. J. Supercond. Nov. Magn. 2012, 25, 2297-2307. [CrossRef]

33. Kurtz, S.K.; Perry, T.T. A powder technique for the evolution of nonlinear optical materials. J. Appl. Phys. 1968, 39, 3798-3812. [CrossRef]

34. Shanshoola, H.M.; Yahaya, M.; Yunus, W.M.M.; Abdullah, I.Y. Z scan Composites. J. Teknol. 2016, 78, $33-38$. 